\title{
Cyclocryotherapy: a review of cases over a 10-year period
}

\author{
M T Benson, M E Nelson
}

\begin{abstract}
There are conflicting reports on the value of cyclocryotherapy in the management of glaucoma. This retrospective study was carried out to assess the efficacy and complication rate of this procedure. The case notes of all patients undergoing cyclocryotherapy at a single centre over a 10 -year period were reviewed. Case records were available for 68 eyes of 64 people. Thirty-eight eyes had neovascular glaucoma, nine had aphakic glaucoma, nine had angle closure glaucoma, three had primary open angle glaucoma, and nine had secondary open angle glaucoma. The mean follow-up periods for these groups varied from 2.0-6.3 years. The mean reduction in intraocular pressure following treatment varied from $7.9 \mathrm{~mm} \mathrm{Hg}$ in the secondary open angle glaucoma group to $24.3 \mathrm{~mm} \mathrm{Hg}$ in those with angle closure glaucoma. Pressure was controlled in $29.4 \%$ overall, ranging from $66.7 \%$ in the angle closure and primary open angle groups to $0 \%$ in the secondary open angle group. Of the painful eyes $71 \%$ were rendered comfortable, indicating that pain relief from cyclocryotherapy is not due solely to pressure control. $30 \%$ of the patients lost their vision following the procedure, phthisis occurred in $11.8 \%$ and four eyes $(5.9 \%)$ went on to enucleation. Our results indicate that cyclocryotherapy affords good pain relief, without good pressure control, in various types of glaucoma. While there is an apparent high complication rate, visual loss and phthisis cannot be ascribed directly to the procedure, since these are eyes with a poor prognosis.
\end{abstract}

Since its description by Bietti in $1950^{1}$ cyclocryotherapy has retained a place in the management of certain types of glaucoma. It is noninvasive and relatively easy to perform, but there are conflicting reports of its efficacy, and some series show a high incidence of visual loss and progression to phthisis in treated eyes. It was therefore decided to carry out a retrospective review of all cases undergoing cyclocryotherapy at our unit over the past 10 years to assess the efficacy and complication rate of this procedure.

Department of

Ophthalmology, Royal Hallamshire Hospital, Sheffield S10 2JF

$M$ T Benson

M E Nelson

Correspondence to: Mr M T Benson.

Accepted for publication 23 August 1989

\section{Materials and methods}

Included in this study are all available case notes of patients undergoing cyclocryotherapy over a 10-year period up to April 1989. Case records were available from 68 eyes of 64 people. The mean age for all patients was 67 years, range 1388 years.

A carbon dioxide cryosurgical unit and a 2.5 $\mathrm{mm}$ probe were used for all procedures. A full description of the operation was not available for all cases, but where indicated typical parameters were a 60-second single freeze, in 6-8 applications, covering $180^{\circ}$ of the ciliary body.

The patients received topical atropine and corticosteroids postoperatively, and in addition glaucoma medication was continued as necessary.

\section{Results}

For the purposes of analysis the cases were categorised as shown in Table 1. Thirty-eight eyes had neovascular glaucoma, of which 26 were due to a central retinal vein occlusion and seven to diabetes. Nine eyes had aphakic glaucoma, nine had angle closure glaucoma, three had primary open angle glaucoma, and nine had secondary open angle glaucoma. The mean follow-up periods for these groups varied from 2.0 to 6.3 years (Table 2 ). The aim of treatment in all groups was reduction in intraocular pressure and/or control of pain. This latter consideration applied particularly to the neovascular group, $87 \%$ of whom had pain preoperatively.

The mean reduction in intraocular pressure following treatment varied from $7.9 \mathrm{~mm} \mathrm{Hg}$ in the group with secondary open angle glaucoma to $24.3 \mathrm{~mm} \mathrm{Hg}$ in those with angle closure (Table $3)$.

An intraocular pressure of more than $0 \mathrm{~mm} \mathrm{Hg}$ but less than $22 \mathrm{~mm} \mathrm{Hg}$ at one month was taken to indicate control of intraocular pressure. By this criterion the pressure was controlled in $29.4 \%$ of eyes overall, ranging from $66.7 \%$ in the angle closure and primary open angle groups to $0 \%$ in the secondary open angle group.

Of those eyes which were painful preoperatively $71 \cdot 4 \%$ were comfortable following the procedure.

The figures for visual acuity changes must be interpreted with caution, since the case notes indicated that of the two patients in the primary open angle glaucoma group who lost vision one had age related macular changes and the other had anterior ischaemic optic neuropathy. If these two cases are ignored, then $30.3 \%$ of patients lost vision following the procedure.

Phthisis was defined as an intraocular pressure of $0 \mathrm{~mm} \mathrm{Hg}$ or a shrunken eye, and this occurred in $11 \cdot 8 \%$ of cases overall.

TABLE I Distribution of glaucoma categories in this series. $S D=$ standard deviation

\begin{tabular}{llll}
\hline Category & Number & \multicolumn{2}{l}{ Mean age SD } \\
\hline Neovascular glaucoma & 38 & 67 & $16 \cdot 9$ \\
Aphakic glaucoma & 9 & 72 & $13 \cdot 5$ \\
Angle closure glaucoma & 9 & 75 & $10 \cdot 8$ \\
Primary open angle glaucoma & 3 & 75 & $9 \cdot 2$ \\
Secondary open angle glaucoma & 9 & 51 & $27 \cdot 6$ \\
\hline
\end{tabular}


TABLE 2 Preoperative data and follow-up periods

\begin{tabular}{|c|c|c|c|c|c|}
\hline & $\begin{array}{l}\text { Neovascular } \\
\text { glaucoma }\end{array}$ & $\begin{array}{l}\text { Aphakic } \\
\text { glaucoma }\end{array}$ & $\begin{array}{l}\text { Angle closure } \\
\text { glaucoma }\end{array}$ & $\begin{array}{l}\text { POA } \\
\text { glaucoma }\end{array}$ & $\begin{array}{l}\text { Secondary } \\
\text { glaucoma }\end{array}$ \\
\hline $\begin{array}{l}\text { IOP } \\
\text { Mean } \\
\text { SD }\end{array}$ & $\begin{array}{l}54 \cdot 8 \\
12 \cdot 4\end{array}$ & $\begin{array}{l}39 \cdot 5 \\
14 \cdot 1\end{array}$ & $\begin{array}{l}46 \cdot 4 \\
11 \cdot 2\end{array}$ & $\begin{array}{l}27 \cdot 3 \\
4 \cdot 6\end{array}$ & $\begin{array}{l}39 \cdot 6 \\
9 \cdot 4\end{array}$ \\
\hline $\begin{array}{l}\text { Acuity } \\
6 / 12+ \\
6 / 18-6 / 60 \\
\text { CF } \\
\text { HM } \\
\text { PL } \\
\text { NPL }\end{array}$ & $\begin{array}{l}0 \\
0 \\
4 \\
9 \\
6 \\
19\end{array}$ & $\begin{array}{l}1 \\
0 \\
3 \\
3 \\
1 \\
1\end{array}$ & $\begin{array}{l}0 \\
1 \\
2 \\
2 \\
0 \\
4\end{array}$ & $\begin{array}{l}3 \\
0 \\
0 \\
0 \\
0 \\
0\end{array}$ & $\begin{array}{l}0 \\
1 \\
1 \\
4 \\
0 \\
3\end{array}$ \\
\hline Pain & 33 & 6 & 4 & 0 & 6 \\
\hline $\begin{array}{l}\text { Follow up: } \\
\text { Mean (years) } \\
\text { Range }\end{array}$ & $\begin{array}{l}2 \cdot 83 \\
0 \cdot 08-9\end{array}$ & $\begin{array}{l}2 \cdot 44 \\
1 \cdot 5-5\end{array}$ & $\begin{array}{l}1 \cdot 98 \\
0 \cdot 02-10\end{array}$ & $\begin{array}{l}6 \cdot 33 \\
5-8\end{array}$ & $\begin{array}{l}2 \cdot 31 \\
0.02-8\end{array}$ \\
\hline
\end{tabular}

$\mathrm{CF}=$ count fingers. $\mathrm{HM}=$ hand movements. $\mathrm{PL}=$ perception of light. $\mathrm{NPL}=$ no perception of light. $P O A$ glaucoma $=$ primary open angle glaucoma. $I O P=$ intraocular pressure.

TABle 3 Postoperative data

\begin{tabular}{|c|c|c|c|c|c|}
\hline & $\begin{array}{l}\text { Neovascular } \\
\text { glaucoma }\end{array}$ & $\begin{array}{l}\text { Aphakic } \\
\text { glaucoma }\end{array}$ & $\begin{array}{l}\text { Angle closure } \\
\text { glaucoma }\end{array}$ & $\begin{array}{l}P O A \\
\text { glaucoma }\end{array}$ & $\begin{array}{l}\text { Secondary } \\
\text { glaucoma }\end{array}$ \\
\hline $\begin{array}{l}\text { Mean IOP } \\
\text { reduction } \\
\text { (mm Hg) }\end{array}$ & $\begin{array}{l}20 \cdot 4 \\
(17 \cdot 8)\end{array}$ & $\begin{array}{l}11 \cdot 8 \\
(12 \cdot 8)\end{array}$ & $\begin{array}{l}24 \cdot 3 \\
(22 \cdot 0)\end{array}$ & $\begin{array}{l}8 \cdot 0 \\
(3 \cdot 6)\end{array}$ & $\begin{array}{l}7 \cdot 9 \\
(8 \cdot 3)\end{array}$ \\
\hline $\begin{array}{l}\text { IOP† } \\
\leq 21 \mathrm{~mm} \mathrm{Hg}\end{array}$ & $\begin{array}{l}10 \\
26 \cdot 3 \%\end{array}$ & $\begin{array}{l}2 \\
22 \cdot 2 \%\end{array}$ & $\begin{array}{l}6 \\
66 \cdot 7 \%\end{array}$ & $\begin{array}{l}2 \\
66 \cdot 7 \%\end{array}$ & 0 \\
\hline Comfortable & $\begin{array}{l}24 / 33 \\
72 \cdot 7 \%\end{array}$ & $\begin{array}{l}5 / 6 \\
83 \cdot 3 \%\end{array}$ & $\begin{array}{l}3 / 4 \\
75 \%\end{array}$ & - & $\begin{array}{l}3 / 6 \\
50 \%\end{array}$ \\
\hline $\begin{array}{l}\text { Vision: } \\
\text { Worse } \\
\text { Same } \\
\text { Improved }\end{array}$ & $\begin{array}{l}13 \\
25 \\
0\end{array}$ & $\begin{array}{l}2 \\
6 \\
1\end{array}$ & $\begin{array}{l}3 \\
6 \\
0\end{array}$ & $\begin{array}{l}2 \\
1 \\
0\end{array}$ & $\begin{array}{l}2 \\
6 \\
1\end{array}$ \\
\hline $\begin{array}{l}\text { Repeat } \\
\text { treatment }\end{array}$ & 4 & 1 & 3 & 0 & 2 \\
\hline Phthisis & 6 & 1 & 1 & 0 & 0 \\
\hline Enucletion & 2 & 0 & 1 & 0 & 1 \\
\hline
\end{tabular}

tAt 1 month.

$\star \mathrm{SD}$ in parentheses. should be evident by this time. ${ }^{+}$Although there was a significant reduction in intraocular pressure in all groups, particularly in neovascular and angle/closure glaucoma, pressure control at one month was disappointing, with only $29 \cdot 4 \%$ of eyes controlled overall and only $26 \cdot 3 \%$ controlled in the neovascular group. This is lower than other published series, which report conrol in $55-66 \%$ of neovascular glaucoma ${ }^{235}$ and 59$67 \%$ overall. ${ }^{237}$ Our results may reflect inadequate technique, since the procedure is performed infrequently, as shown by the record of only 68 such operations over a 10 -year period, and experience in the technique is therefore limited. The variation in technique recorded in the case notes supports this notion.

Cyclyocryotherapy decreases aqueous production by damaging the ciliary epithelium and the vascular supply to the ciliary body. The destructive effect depends on the freezing rate and the tissue temperature achieved. At $-15^{\circ} \mathrm{C}$ extracellular water crystallises, leading to increased extracellular concentration of electrolytes, with resulting cellular dehydration and disruption. Below $-15^{\circ} \mathrm{C}$ intracellular ice crystals form, causing far greater damage. ${ }^{+}$

To ensure placement over the pars plicata a 2.5 mm probe should be used, and this should be placed $1 \mathrm{~mm}$ from the limbus nasally, temporally, and inferiorly, and $1.5 \mathrm{~mm}$ superiorly. ${ }^{+8} \mathrm{~A}$ freeze temperature of $-80^{\circ} \mathrm{C}$ is desirable to produce a toxic concentration of electrolytes. ${ }^{+}$The freeze time should be longer than 30 seconds so that the changes occurring in cells can cause permanent damage. At $-80^{\circ} \mathrm{C}$ a 60 -second application appears to be most appropriate. ${ }^{3}$ There is a direct relationship between the extent of treatment and intraocular pressure reduction, and this parallels the histological changes resulting from treatment. ${ }^{9}$ Most of the serious complications (hypotony, phthisis bulbi) are found after $360^{\circ}$ treatment. ${ }^{3}$ The initial treatment should therefore be limited to one hemisphere.

Despite poor pressure control in our series, the procedure rendered $71.4 \%$ of painful eyes comfortable. This indicates that pain relief from cyclocryotherapy is not due solely to pressure control.

The visual loss from other causes in two of the patients with open angle glaucoma indicates that caution must be exercised when attributing decrease in visual acuity to the cyclocryotherapy. It must be borne in mind that the majority of these patients are elderly (mean 67 years) and that these are unhealthy eyes, many of which have a poor prognosis regardless of treatment. Our rate of visual loss of $30 \%$ overall and $34 \%$ in neovascular glaucoma is relatively low. Brindley and Shields ${ }^{2}$ report a $60 \%$ visual loss overall and $68 \%$ in the neovascular group. Other published figures for visual loss in the latter group are $70 \%^{3}$ and loss of light perception in $37-59 \% .{ }^{56}$ If the two patients with primary open angle glaucoma who lost vision are excluded, then of our patients who lost vision only two out of 20 achieved control of intraocular pressure. It may be therefore, that it is failure to lower the intraocular pressure which is responsible for visual loss rather than the procedure itself.

Our figure of $11 \cdot 8 \%$ progression to phthisis
Discussion
In our series neovascular glaucoma forms the
largest group, comprising $56 \%$ of cases. This
group accounted for $51 \%$ of cases reported by
Brindley and Shields and only $21 \%$ of the series
reported by Caprioli et al. ${ }^{3}$ The difference may
reflect the fact that these reports are from
specialist glaucoma centres.
The intraocular pressure at one month after
operation, or as soon as possible after that, was
chosen because the full effect of the procedure

Discussion
In our series neovascular glaucoma forms the
largest group, comprising $56 \%$ of cases. This
group accounted for $51 \%$ of cases reported by
Brindley and Shields and only $21 \%$ of the series
reported by Caprioli et al. ${ }^{3}$ The difference may
reflect the fact that these reports are from
specialist glaucoma centres.
The intraocular pressure at one month after
operation, or as soon as possible after that, was
chosen because the full effect of the procedure

Discussion
In our series neovascular glaucoma forms the
largest group, comprising $56 \%$ of cases. This
group accounted for $51 \%$ of cases reported by
Brindley and Shields and only $21 \%$ of the series
reported by Caprioli et al. ${ }^{3}$ The difference may
reflect the fact that these reports are from
specialist glaucoma centres.
The intraocular pressure at one month after
operation, or as soon as possible after that, was
chosen because the full effect of the procedure

Discussion
In our series neovascular glaucoma forms the
largest group, comprising $56 \%$ of cases. This
group accounted for $51 \%$ of cases reported by
Brindley and Shields ${ }^{2}$ and only $21 \%$ of the series
reported by Caprioli et al. ${ }^{3}$ The difference may
reflect the fact that these reports are from
specialist glaucoma centres.
The intraocular pressure at one month after
operation, or as soon as possible after that, was
chosen because the full effect of the procedure 
(15.8\% in the neovascular group) accords with other series. Caprioli $e t a l^{3}$ reported phthisis in $12 \%$ with $360^{\circ}$ treatment and in $6 \%$ with $180^{\circ}$ treatment. Brindley and Shields ${ }^{2}$ found $12 \%$ overall and $22 \%$ in the neovascular group. Krupin and Mitchell ${ }^{6}$ noted phthisis in $14 \%$ of neovascular cases at 12 months, and in 34\% ultimately, with mean follow-up of 24.9 months and phthisis developing at a mean of 14.4 months. Although our figures were too small for statistical analysis, it was noted that of the seven patients with phthisis for whom operative details were recorded the extent of treatment was $360^{\circ}$ in four, $270^{\circ}$ degrees in two, and $180^{\circ}$ in only one (Table 4). Overall, the extent of treatment was $180^{\circ}$ in $35,270^{\circ}$ in $11,360^{\circ}$ in 13 , and unknown in nine. This lends support to the notion that no more than $180^{\circ}$ should be treated at a single session.

Our results indicate that cyclocryotherapy affords good pain relief, without good pressure control, in various types of glaucoma. While there is an apparent high complication rate, visual loss and phthisis cannot be ascribed directly to the procedure, since these are eyes with a poor prognosis. It should be borne in mind that prevention of rubeotic glaucoma is paramount, and that there are very favourable reports for the use of photcoagulation combined with modified filtration surgery for neovascular glaucoma. ${ }^{111}$

1 Bietti G. Surgical intervention on the ciliary body; new trends for the relief of glaucoma. FAMA $1950 ; 142 ; 889-97$.

2 Brindley G, Sheilds MB. Value and limitations of cyclocryotherapy. Graefes Arch Clin Exp Ophthalmol 1986; 224: 545-8.

3 Caprioli J, Strang SL, Spaeth GL. Proyzees EH. Cyclocryotherapy in the treatment of advanced glaucoma. Ophthalmology 1985; 92: 947-53.

4 Prost M. Cyclocryotherapy for glaucoma. Evaluation of techniques. Surv Ophthalmol 1983; 28: 93-100.

5 Feibel RM, Bigger JF. Rubeosis iridis and neovascular glaucoma. Evaluation of cyclocryotherapy. Am $\mathcal{F}$ Ophthalmol 1972; 74: 862-7.

6 Krupin T, Mitchell KB. Cyclocryotherapy in neovascular glaucoma. Am $\mathcal{F}$ Ophthalmol 1978; 86: $24-6$.

7 Bellows AR, Grant WM. Cyclocryotherapy in advanced inadequately controlled glaucoma. Am $\mathcal{F}$ Ophthalmol 1973; 75: 679-84.

8 Prost $M$. Anatomy of the ciliary body and cyclocryotherapy. Opthalmologica 1984; 188: 9-13.

9 Higginbotham EJ, Lee DA, Bartels SP, Richardson T, Miller $M$. Effects of cyclocryotherapy on aqueous humour dynamics in cats. Arch Ophthalmol 1988; 106: 396-403.

10 Allen RC, Bellows AR, Hutchinson BT, Murphy SD. Filtration surgery in the treatment of neovascular glaucoma. Ophthalmology 1982; 89: 1181-7.

11 Parrish R, Herschler J. Eyes with end-stage neovascular glaucoma. Natural history following successful modified filtering operation. Arch Ophthalmol 1983; 101: 745-6. 